\title{
Apparent Mineralocorticoid Excess Syndrome: An Overview
}

\begin{abstract}
Apparent mineralocorticoid excess (AME) syndrome results from defective $11 \alpha$-hydroxysteroid dehydrogenase type $2(11 \alpha-H S D 2)$. This enzyme is co-expressed with the mineralocorticoid receptor (MR) in the kidney and converts cortisol $(F)$ to its inactive metabolite cortisone (E). Its deficiency allows the unmetabolized cortisol to bind to the MR inducing sodium retention, hypokalemia, suppression of PRA and hypertension. Mutations in the gene encoding $11 \alpha-H S D 2$ account for the inherited form, but a similar clinical picture to AME occurs following the ingestion of bioflavonoids, licorice and carbenoxolone, which are competitive inhibitors of $11 \alpha-\mathrm{HSD} 2$. Reduced $11 \alpha-\mathrm{HSD} 2$ activity may explain the increased sodium retention in preeclampsia, renal disease and liver cirrhosis. Relative deficiency of $11 \alpha-H S D 2$ activity can occur in Cushing's syndrome due to saturation of the enzyme and explains the mineralocorticoid excess state that characterizes ectopic ACTH syndrome. Reduced placental $11 \alpha-H S D 2$ expression might explain the link between reduced birth weight and adult hypertension. Polymorphic variability in the HSD11B2 gene in part determines salt sensitivity, a forerunner for adult hypertension onset. AME represents a spectrum of mineralocorticoid hypertension with severity reflecting the underlying genetic defect in the $11 \alpha-H S D 2$; although AME is a genetic disorder, several exogenous compounds can bring about the symptoms by inhibiting $11 \alpha-\mathrm{HSD} 2$ enzyme. Substrate excess as seen in Cushing's syndrome and ACTH ectopic production can overwhelm the capacity of $11 \alpha-H S D 2$ to convert $F$ to $E$, leading up to an acquired form of AME. (Arq Bras Endocrinol Metab 2004;48/5:687-696)
\end{abstract}

Keywords: Hypertension; $11 \alpha-H S D 2$; AME syndrome; Cortisol; Cortisone

\section{RESUMO}

\author{
Síndrome do Excesso Aparente de Mineralocorticóides: Uma \\ Revisão.
}

A síndrome do excesso aparente de mineralocorticóides (SEAM) resulta de defeito na $11 \alpha$-hidroxisteróide desidrogenase tipo 2 ( $11 \alpha-H S D 2)$. Esta enzima é co-expressa com o receptor mineralocorticóide (RM) nos rins e converte cortisol $(F)$ em cortisona $(E)$, seu metabólito inativo. Deficiência desta enzima permite que o cortisol não metabolizado se ligue ao RM, induzindo retenção de sódio, hipocalemia, supressão da APR e hipertensão. Mutações no gene que codifica a $11 \alpha-H S D 2$ são responsáveis pela forma herdada, mas um quadro clínico semelhante de SEAM ocorre durante ingestão dos bioflavonóides, alcaçuz e carbenoxolona, que são inibidores competitivos da $11 \alpha-H S D 2$. Redução na atividade da $11 \alpha-H S D 2$ pode explicar o aumento da retenção de sódio na pré-eclâmpsia, na doença renal e na cirrose hepática. Deficiência relativa de atividade da $11 \alpha-H S D 2$ pode ocorrer na síndrome de Cushing devido à saturação da enzima e explicar o estado de excesso mineralocorticóide que caracteriza a síndrome do ACTH ectópico. Redução da expressão placentária da $11 \alpha$-HSD2 poderia justificar a ligação entre baixo peso ao nascer e hipertensão no adulto. Variabili-

\author{
Mario Palermo \\ Marcus Quinkler \\ Paul M. Stewart
}

\author{
Institute of Endocrinology, \\ University of Sassari (MP), \\ Sassari, Italy; and Division of \\ Medical Sciences, University of \\ Birmingham, Queen Elizabeth \\ Hospital (MQ PMS), Edgbaston, \\ Birmingham, UK.
}


dade polimórfica no gene HSD1 1B2 determina, em parte, a sensibilidade ao sódio, um preditor do surgimento da hipertensão no adulto. A SEAM representa um espectro de hipertensão mineralocorticóide cuja severidade reflete o defeito genético de base na $11 \alpha-H S D 2$; embora a SEAM seja uma doença genética, vários compostos exógenos podem provocar os sintomas pela inibição da $11 \alpha-H S D 2$. O excesso de substrato, visto na síndrome de Cushing e na produção ectópica de ACTH, pode sobrepujar a capacidade da $11 \alpha-H S D 2$ de converter $F$ em $E$, levando a uma forma adquirida de SEAM. (Arq Bras Endocrinol Metab 2004;48/5:687-696)

Descritores: Hipertensão; $11 \alpha-H S D 2 ;$ Síndrome do EAM; Cortisol; Cortisona

A PPARENT MINERALOCORTICOID EXCESS SYNDROME (AME) is characterized by clinical features suggesting excessive production of a mineralocorticoidlike substance with hypertension, plasma volume expansion, hypokalemic alkalosis and a suppressed renin-angiotensin-aldosterone system (1). It can be classified on the basis of whether it is congenital or acquired, but the two forms share the same pathophysiology: AME is the outcome of defective $11 \alpha-$ hydroxysteroid dehydrogenase type 2 (11 $\alpha$-HSD2) $(2,3)$. This enzyme is predominantly expressed, together with the mineralocorticoid receptor (MR), in the renal distal tubules and collecting ducts (4), in the distal colon, in the salivary glands and also in the placenta where it protects the fetus from an excessive amount of maternal cortisol (F) $(5,6)$ (figure 1). $11 \alpha-$ HSD2 converts $\mathrm{F}$ to its inactive metabolite cortisone (E). Since F, but not E, is a potent agonist of epithelial type 1 mineralocorticoid receptors, reduced activity or total deficiency of the enzyme exposes the kidney to an excess of $\mathrm{F}$, which can then act as a potent mineralocorticoid $(7,8)$. Mineralocorticoid receptor (MR) has the same affinity for $\mathrm{F}$ and aldosterone in vitro (9), and the inactivation of cortisol to cortisone by $11 \alpha-$ HSD2 at the site of the MR enables aldosterone to bind to this receptor in vivo (figure 2) (10). Aldos-

\begin{tabular}{lll}
\hline & $11 \alpha-$ HSD type I & 11 $\alpha$-HSD type II \\
\hline Location & Liver, adipose tissue & Kidney, colon, placenta \\
Cofactor & NADP+ & NAD+ \\
Substrate affinity & Low & High \\
Bi-directional? & Yes, mainly reductase & No, only dehydrogenase \\
DNA & $1287 \mathrm{bp}$ & $1840 \mathrm{bp}$ \\
Aminoacids & 292 & 405 \\
Molecular mass & $34 \mathrm{kDa}$ & $45 \mathrm{kDa}$ \\
Chromosome & 1 & 16 \\
\hline
\end{tabular}

Figure 1. $11 \alpha+H y d r o x y s t e r o i d$ dehydrogenase (11 $\alpha \mathrm{HSD})$ isozymes. terone is not metabolized by $11 \alpha$-HSD 2 because it forms a $\mathrm{C}_{11}-\mathrm{C}_{18}$ hemi-ketal group in aqueous solution.

Circulating levels of adrenal corticosteroids and $11 \alpha$-HSD 2 activity are then involved in blood pressure regulation. Their importance is highlighted by pathophysiological situations such as Cushing's syndrome or ectopic production of ACTH, but even in essential hypertension decreased activity of $11 \alpha-\mathrm{HSD} 2$ has been described.

A distinct isozyme of $11 \alpha$-hydroxysteroid dehydrogenase exists ( $11 \alpha-\mathrm{HSDl})$. It is widely distributed, but most abundant in liver and adipose tissue. It functions mainly as an oxoreductase, converting cortisone to cortisol, and plays a crucial role in the organ-specific modulation of F effect (11) (figure 1).

This review discusses the consequence of congenital or acquired deficiency of $11 \alpha$-HSD 2 activity, in humans.

\section{CONGENITAL DEFICIENCY OF $11 \alpha-H S D 2$}

\section{Apparent Mineralocorticoid Excess Syn- drome}

\section{Cortisol metabolism}

To understand the metabolic consequence of defective $11 \alpha$-HSD 2 activity, it is important to know the normal metabolism of $\mathrm{F}$.

Cortisol is interconverted with cortisone by $11 \alpha$-HSD 2 and the principal site of conversion is the kidney (12), whilst the liver is the place where corti-

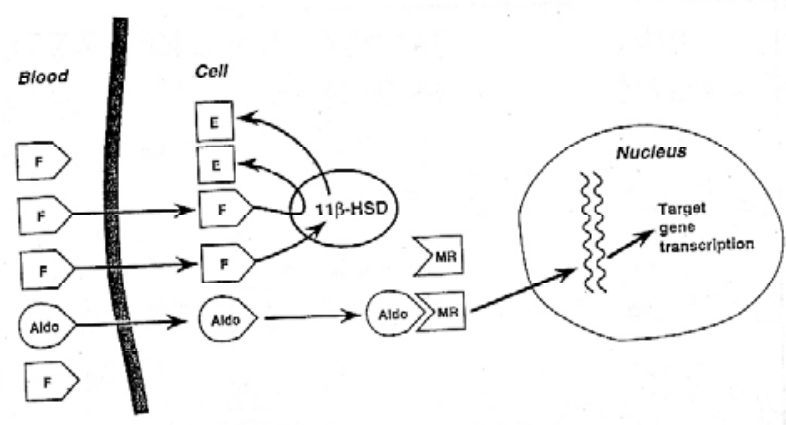

Figure 2. Pathophysiology of apparent mineralocorticoid excess syndrome. The mineralocorticoid receptor (MR) binds aldosterone $(A)$ and cortisol $(F)$ with equal affinity. Plasma $F$ concentrations exceed those of $A$ by a 100 -fold. $11 \alpha-H S D$ by inactivating $F$ to $E$, enables aldosterone to bind to MR. After binding of A to the MR, the A-MR complex binds to DNA hormone response elements and increases transcription of target genes. In the case of impaired 11 aHSD2 activity, $F$ binds inappropriately to the MR and increases transcription of MR target genes leading to sodium resorption and potassium excretion. 
sone is mainly converted to cortisol by $11 \alpha$-HSDl. Both are substrates for a series of enzymatic activities in the liver, including the reduction of $\alpha^{4}$ double bond (yields $5 \alpha$ - and $5 \alpha$-dihydrocortisol and $5 \alpha$ - and $5 \alpha$ dihydrocortisone), reduction of 3-keto group (yields $5 \alpha$ - and $5 \alpha$-tetrahydrocortisol and $5 \alpha$ - and $5 \alpha$-tetrahydrocortisone), reduction of 20-keto group (yields to $20 \alpha$ - and $20 \alpha-\mathrm{DHF}$, cortols and cortolones) (figure $3)$. Most of the products are excreted in the urine as glucuronides. Only a small part of cortisol metabolites is excreted unconjugated mainly as 3-oxo-4-ene steroids (36).

In the case of AME (partial or complete deficiency of $11 \alpha$-HSD2), urinary steroid metabolite profiles indicate that the majority of cortisol metabolites are excreted as A-ring reduced metabolites of cortisol itself ( $5 \alpha$-tetrahydrocortisol (THF) and $5 \alpha$-THF or allo-THF) with very low or absent levels of tetrahydrocortisone (THE) in the urine. The excretion of $5 \alpha-$ cortisol metabolites exceeds that of $5 \alpha$-cortisol metabolites and results in a high urinary allo- $\mathrm{THF} / \mathrm{THF}$ ratio sug-

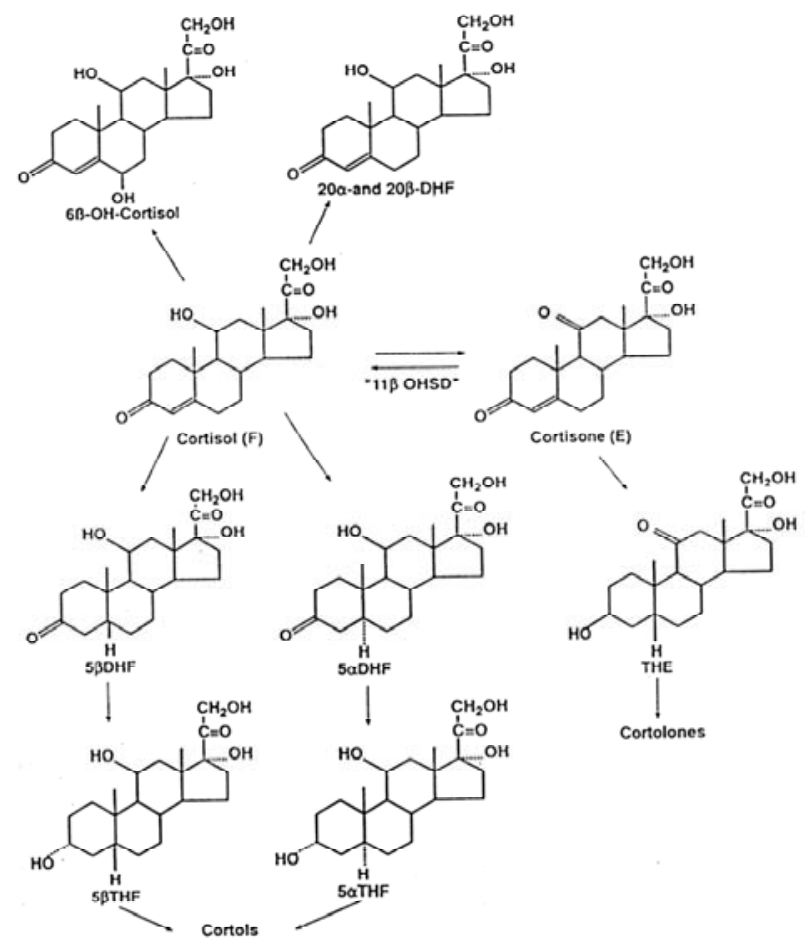

Figure 3. Cortisol metabolism. 11 $\alpha$-HSD2 deficiency reduces the production of THE; as a consequence, (THF+alloTHF)/THE ratio increases. Despite normal circulating cortisol levels, patients with AME show a decrease in the total urinary excretion of cortisol metabolites reflecting a reduction secretion rate consequent upon a prolonged plasma halflife. In addition, $5 \alpha$-reduced cortisol metabolites predominate over $5 \alpha$-reduced cortisol metabolites consistent with a reduction of $5 \alpha$-reductase activity in patients with AME. gesting an additional defect in $5 \alpha$-reductase activity $(13,14)$. The incremental increase in the THF+allo$\mathrm{THF} / \mathrm{THE}$ compared to the allo-THF/THF ratio, however, is much larger, with typical THF+allo$\mathrm{THF} / \mathrm{THE}$ ratios ranging from 3 to over 70 in AME (normal ratio is approximately $\mathrm{l}$ ). The $\mathrm{THF}+$ allo$\mathrm{THF} / \mathrm{THE}$ ratio has been used in the past in the diagnosis of AME $(13,14)$, but probably provides an index of "global" $11 \alpha$-HSD activity within the body, i.e. principally $11 \alpha-\mathrm{HSD} 1$ in the liver and $11 \alpha-\mathrm{HSD} 2$ in the kidney. The conversion of cortisone to cortisol mediated by $11 \alpha-\mathrm{HSDl}$ is normal in AME (67). The plasma half-life of $\left[11^{-3} \mathrm{H}\right]$-cortisol (which when metabolized by $11 \alpha-H S D$ yields tritiated water and cortisone) may more accurately reflect renal $11 \alpha-$ HSD2 activity (10), as may the ratio of urinary free cortisol/urinary free cortisone (UFF/UFE) (15). Normal subjects excrete 2-3-fold more UFE than UFF, reflecting the significant activity of renal $11 \alpha$-HSD2. In AME, however, UFE excretion is virtually undetectable (16) resulting in a high UFF/UFE ratio. Plasma cortisol half-life is prolonged (120-190min vs. $70-90 \mathrm{~min}$ in controls), but patients with AME are not cushingoid; the cortisol secretion rate falls often to very low levels due to a normal intact negative feedback mechanism. This maintains normal circulating concentrations in the face of impaired cortisol metabolism.

A variant of AME, so-called "type II AME" has been documented in several patients $(17,18)$. This variant is characterized by a milder phenotype, with onset in late adolescence or early adulthood and only a mildly deranged urinary $\mathrm{THF}+$ allo-THF/THE ratio. However, the UFF/UFE excretion is high in the type II variant, and the metabolism of 11 -triated cortisol

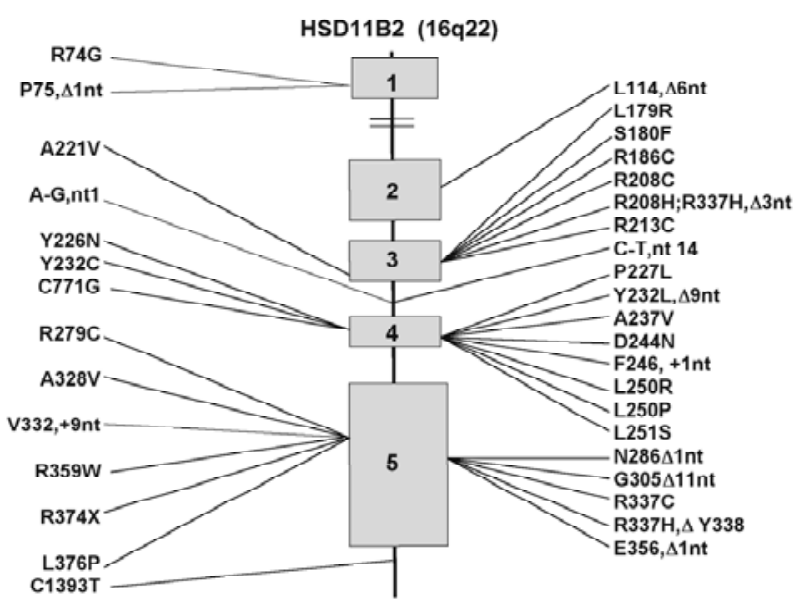

Figure 4. Mutations and their location in the HSD 11 B2 gene leading to Apparent Mineralocorticoid Excess (AME) syndrome. Exons= gray squares. 
(directly reflecting $11 \alpha$-HSD2 dehydrogenase activity) is grossly deranged, confirming deficiency of $11 \alpha-$ HSD2 (16) (figure 5A).

\section{Pathophysiology}

The pathophysiology of AME has now been satisfactorily explained in terms of its clinical, biochemical and genetic basis. An inability of the renal $11 \alpha-\mathrm{HSD} 2$ enzyme to inactivate $\mathrm{F}$ to $\mathrm{E}$ is the cause of sodium retention, PRA and aldosterone suppression and hypertension.

Firstly, in 1974 Werder et al. (19) described a child with features similar to primary hyperaldosteronism, but presenting suppressed plasma aldosterone. Afterwards, New et al. (20) and Ulick et al. (21) described other children presenting similar clinical pictures. The distinctive feature of the patients was the high excretion of $11 \alpha$-hydroxycortisol metabolite (THF and cortols) to the extremely low excretion of 11-oxo-metabolites (THE and cortolones). Since hypertension, low renin and hypokalemia, but low levels of aldosterone and deoxycorticosterone were present, the term "Apparent Mineralocorticoid Excess" (AME) was coined. In 1983, Oberfield et al. (22) documented the mineralocorticoid effect of hydrocortisol and the marked hypotensive effect of spironolactone and metyrapone. For these reasons, they suggested the presence of a defective conversion of $\mathrm{F}$ to $\mathrm{E}$ and a mineralocorticoid-like action of cortisol on MR (22). In 1985, the first adult case of AME was reported. It was described the beneficial effect of dexamethasone and the deleterious action of hydrocortisone on blood pressure and hypokalemia in this patient, confirming the involvement of a deranged cortisol metabolism in the pathogenesis of the syndrome (23). The physiological explanation of this theory was given by the demonstration that the MR has the same affinity for cortisol and aldosterone in vitro, but $11 \alpha-H S D$ protects the MR in vivo by the action of $\mathrm{F}$ hundreds of times higher in concentration compared to aldosterone $(9,24)$. This enzyme was then proposed as the one responsible for the syndrome. In 1989, Ulick et al. (25) described the case of 4 Italian children with the same clinical presentation of classical AME, but less severe biochemical features. They called this syndrome AME type II (25). On the basis of the markedly decreased ring-A reduction constant (THF+alloTHF/F), they indicated the impaired ring-A reduction and/or defective interconversion of $\mathrm{F}$ and $\mathrm{E}$ in both directions ( $\mathrm{F}$ to $\mathrm{E}$ and $\mathrm{E}$ to $\mathrm{F}$, leaving the ratio between 11- $\alpha$ and 11-oxo steroid unchanged) as the principal abnormalities of $\operatorname{AME}(25,26)$. In 19951996, information on the structure and sequence of the HSD11B2 gene has enabled the identification of mutations in AME patients. HSDl lB2 is $6.2 \mathrm{~kb}$ in length containing five exons and is located on chromosome 16q22 $(27,28)$. At present, more than 30 different mutations have been defined within the HSD11B2 gene in approximately 60 affected kindreds (figure 3) (3,28-30). Genetics entirely explain the clinical and biochemical features of AME.

The congenital form of AME is thus attributable to deficiency of $11 \alpha$-HSD2. Cortisol and aldosterone have similar affinities in vitro for the type I MR and $11 \alpha-H S D 2$ confers aldosterone specificity on the intrinsically non-specific MR by converting cortisol to its inactive metabolite cortisone. This way, $11 \alpha$-HSD2 in vivo protects MR from the hundreds of times higher circulating levels of cortisol.

AME is an autosomal recessive inherited form of hypertension. Most type I AME patients are homozygous for HSD11B2 mutations causing full, or partial loss of activity. It is most commonly found in consanguineous families $(3,28,30,31)$.

Type II AME is also explained on the basis of mutations in the HSD11B2 gene $(32,33)$. In an extensive Sardinian kindred, a novel homozygous mutation (R279C) was found in all 4 affected cases. In keeping with the mild phenotype the mutation resulted in a mutant enzyme with only minor disturbances in activity. Classification of AME into distinct variants is therefore inappropriate (figure 5A). In keeping with this, a close correlation is reported between disease phenotype (as measured by the THF+allo-THF/THE ratio, serum potassium and blood pressure) and genotype (34). Patients with mutant $11 \alpha$-HSD2 cDNAs that demonstrate little or no activity in vitro, present in early life with severe, often life-threatening, hypertension and hypokalemia. In contrast patients presenting in late adolescence or early adulthood with socalled "mild" forms of AME have been found to have mutations that result in an $11 \alpha-\mathrm{HSD} 2$ protein with only attenuated activity.

\section{Clinical Picture}

In its full expression AME is rare, with fewer than 100 cases reported worldwide, but presentation is dramatic. Usually patients are children with low birth weight, failure to thrive, short stature, and severe, often fatal, hypertension with hypokalemic metabolic alkalosis and muscle weakness. Hypokalemic nephropathy sometimes causes nephrocalcinosis, polycystic kidney and nephrogenic diabetes insipidus manifesting as thirst and polyuria. Renal insufficiency is not rare. Severe hypertension causes left ventricular hypertrophy, car- 
diomegaly and hypertensive retinopathy. The mortality is more than $10 \%$, due to stroke, cerebral hemorrhage and infarction. Less severe forms in adults have been described. These patients were in the past included in the type II AME. The less severe biochemical and clinical features in type II patients compared to type I appear to be explained on the basis of mutations, which result in some residual functional enzy-
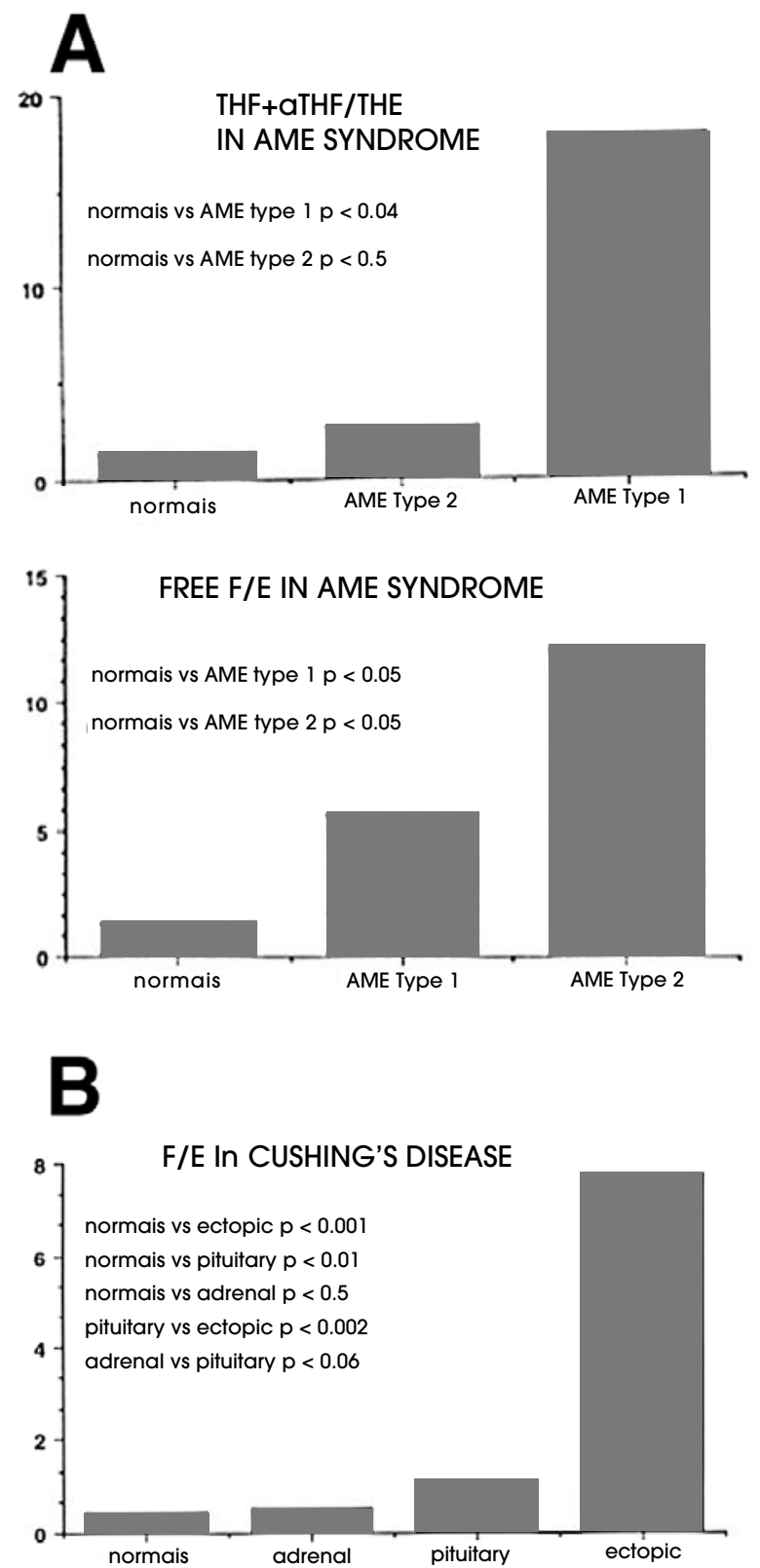

Figure 5. A) (THF+allo-THF)/THE and UFF/UFE are significantly increased both in AME type I and type II. B) $11 \alpha$-Hydroxysteroid dehydrogenase is saturated by substrate excess. Increase in UFF/UFE ratio depends by the amount of circulating cortisol. matic activity. The decision to assign the individual patients to AME type I or II group is therefore rather arbitrary $(35,18)$ (figure $5 \mathrm{~A})$.

\section{Diagnosis}

Biochemical abnormalities comprise suppressed PRA, undetectable serum aldosterone levels and hypokalemia. Traditionally, the THF+alloTHF/THE ratio has been used in the diagnosis of AME. A very high ratio can be found (normal ratio ranges from 1 to 3 ) together with evidence of a more general defect in steroid ring-A reduction (i.e. a higher allo- $\mathrm{THF} / \mathrm{THF}$ ratio and a lower ring-A reduction constant $\mathrm{THF}+$ allo- $\mathrm{THF} / \mathrm{F}$ ).

The "net" in vivo conversion of $\mathrm{F}$ to $\mathrm{E}$ involves both isoforms of $11 \alpha$-HSD in tissue expressing these enzymes. As AME is a disorder of the renal $11 \alpha-$ HSD2, a direct measure of the ratio of urinary free cortisol/free cortisone fractions (UFF/UFE) should better reflect $11 \alpha$-HSD2 isozyme activity with respect to the ratio of liver-reduced metabolites (THF+alloTHF)/THE $(15,16,36)$. As a consequence, UFF/UFE ratio proves extremely sensitive and accurate when used as an index of clinical disorder. In 24 patients suffering from AME syndrome, where urinary $\mathrm{E}$ is virtually absent, THE was always detectable although 12 subjects had undetectable UFE (16). This suggests that UFE may be more sensitive than THE in the diagnosis of AME. Moreover, if used in monitoring the enzymatic activity in heterozygotes, we often found a significant increase in UFF/UFE ratio, but not in the (THF+allo-THF)/THE ratio (37). A comparison of the UFF/UFE to (THF+allo-THF)/THE ratios in patients with $\mathrm{AME}$ after licorice ingestion or in patients suffering from ectopic ACTH syndrome, shows that any deviation from normal in the (THF+allo-THF)/THE ratio resulted in a much more marked change in UFF/UFE (15). The higher sensitivity of UFF/UFE probably occurs because it derives from the activity of the renal isozyme $11 \alpha$-HSD2, expressed together with the MR in the distal tubule and collecting duct, whereas the reduced fraction THF, allo-THF and THE are products of the hepatic metabolism of $\mathrm{F}$ (38).

AME patients are not cushingoid because they have a normal intact negative feedback mechanism. This maintains normal circulating concentration in the face of impaired cortisol metabolism.

Figure 6 illustrates how AME might be diagnosed in a patient presenting with mineralocorticoid excess.

\section{Therapy}

Therapy is directed at correcting life-threatening 


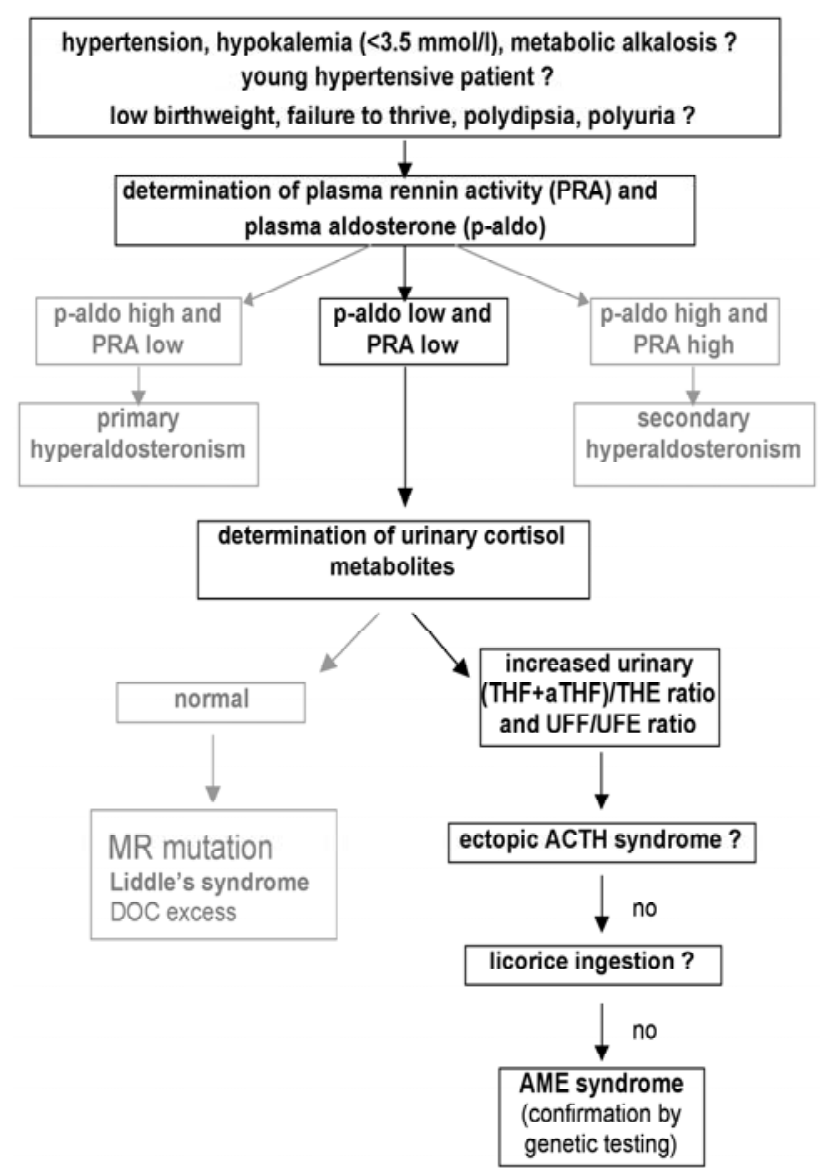

Figure 6. Flowsheet with guidelines for detecting Apparent Mineralocorticoid Excess (AME) syndrome. THF= tetrahydrocortisol; aTHF= allo-tetrahydrocortisol; $\mathrm{THE}=$ tetrahydrocortisone; UFF= urinary free cortisol; UFE= urinary free cortisone.

hypokalemia and hypertension $(18,35)$. Dexamethasone is the treatment of choice. Doses ranging from 1.5 to $2 \mathrm{mg}$ /day brought serum potassium levels to normal in 7-10 days in approximately $60 \%$ of cases by suppressing cortisol and progressively decreasing blood pressure. Additional antihypertensive medication may be required. Patients have been successfully treated with the potassium sparing diuretics triamterene and/or amiloride. Thiazide diuretics are indicated when hypercalciuria and/or nephrocalcinosis are present. Spironolactone, a MR antagonist, has been of variable benefit, presumably because very high doses are required to block the mineralocorticoid effects of cortisol on the MR. Its side effects include menstrual disturbances in women, gynecomastia, impotence and decreased libido in men and are mainly due to its inhibition of steroid biosynthetic P-450 enzyme and its action as an antiandrogen. Sometimes it is important to reduce dietary sodium. AME was reported "cured" in one patient following kidney transplantation due to the normal $11 \alpha$-HSD 2 activity of the transplanted kidney (39). The case suggests a new strategy in a selected cohort of patients such as drug-unresponsive children and in patients with endstage kidney failure.

\section{$11 \alpha$-HSD2 and "Essential" Hypertension}

Although patients with essential hypertension do not have overt signs of mineralocorticoid excess, some positive correlations between blood pressure and plasma sodium levels or a negative correlation with serum potassium levels have been described.

Regarding $11 \alpha$-HSD2, studies have demonstrated variations in $11 \alpha-\mathrm{HSD}$ activity in hypertensive subjects with either increases in the plasma $\left[11^{\sim}-3 \mathrm{H}\right]$ cortisol half-life or the $\mathrm{THF}+$ allo- $\mathrm{THF} / \mathrm{THE}$ ratio $(40,41)$, but mineralocorticoid excess in patients with impaired $11 \alpha$-HSD 2 activity could not be demonstrated.

Recently, association and linkage studies have been performed. One study has reported an association between a microsatellite marker close to the HSD11B2 gene and hypertension in African Americans with hypertensive end stage renal disease (42). These data were confirmed using a polymorphic restriction site in exon 3 of the HSD11B2 gene. In terms of hypertension per se, however, linkage and/or association studies have been negative $(43,44)$.

Increased sensitivity to salt is a forerunner to "essential" hypertension. Salt sensitive individuals appear to have impaired $11 \alpha$-HSD2 activity as measured by increased urinary cortisol/cortisone ratios. Studies have evaluated a microsatellite within intron 1 of the HSD11B2 gene, and documented association with salt sensitivity in both normal subjects and patients with hypertension $(45,46)$. Short microsatellite alleles were more common in salt sensitive compared to salt resistant subjects. The same phenomenon was observed in Blacks compared to Caucasians (47), in keeping with the predisposition to low-renin, saltsensitive hypertension in this ethnic group.

In addition to enhanced renal sodium retention, the modulation of active glucocorticoid concentration by $11 \alpha$-HSD in vascular smooth muscle cells could be an additional factor underlying hypertension (48). In vitro and in vivo studies indicate that $11 \alpha-$ HSDs regulate vascular tone at an autocrine level through the amplification of responses to vasoconstrictors (49). Inhibition of $11 \alpha$-HSD2 in vascular smooth muscle cells resulted in increased responses to angiotensin-II (50) and phenylephrine (51). $11 \alpha-$ 
HSD2 knockout mice demonstrate increased arterial reactivity to norepinephrine and decreased endothelium-derived nitric oxide synthase activity (52).

\section{ACQUIRED DEFICIENCY OF $11 \alpha-H S D 2$}

\section{Licorice}

Licorice roots and their extract have been used for over one thousand years as a medical herb product and as sweeteners and mouth fresheners (53). The active ingredient of licorice is glycyrrhizic acid, which is hydrolyzed into its aglicone glycyrrhetinic acid in vivo. Licorice products are made from peeled and unpeeled dried root. There are powdered and finely cut root preparations; the most important are the liquid and the dry extracts. These formulations have different concentrations of the active ingredient, glycyrrhizic acid, and can vary from $20 \%$ to trace amount, based on the extraction process. In addition, a number of commercial preparations containing licorice are available such as herboristic and cosmetic; moreover some preparations are used as a cough remedy and are usually mixed with Arabic gum, sugar, alcohol and tobacco. A preparation of the root of the licorice plant was successfully used to treat patients with peptic ulceration. Such observations were the basis for the development of the effective anti-ulcer drug, carbenoxolone, which is a hemisuccinate derivative of $18 \alpha-\mathrm{gly}$ cyrrhetinic acid. Licorice possesses some endocrinological effects such as glucocorticoid activity, antiandrogen effect, and estrogenic activity. Whorwood (54) described an inhibitory effect of licorice on prolactin gene expression in vivo. Its mineralocorticoid effect was first documented in the 1940's. Patients consuming excessive quantities of licorice present with hypertension and hypokalemia, which may be severe enough to cause myopathy and cardiac arrhythmia. Both PRA and aldosterone levels are suppressed and exchangeable sodium levels are increased. The condition responds to spironolactone and is reversible upon stopping licorice ingestion (55). Glycyrrhizic and glycyrrhetinic acids have a very low affinity for the MR, but are very potent competitive inhibitors of $11 \alpha$ HSD2 (Ki of approx. 5-10nM) (56). Licorice administration to normal volunteers results in a mineralocorticoid excess state, an increase in the urinary $\mathrm{THF}+$ allo-THF/THE ratio, an increase in plasma cortisol half-life, and a decrease in circulating cortisone values, indicative of inhibition of $11 \alpha$-HSD 2 in vivo. Thus it is now established that licorice induces an acquired and milder form of AME, causing its mineralocorticoid effects through inhibition of $11 \alpha$-HSD2.

\section{Flavonoids Consumption}

The flavonoids naringin and its aglycone naringenin present in some kind of fruits, such as grapefruit, seem to have an inhibitory effect on $11 \alpha$-HSD 2 similar to licorice. In sensitive individuals, $250 \mathrm{mg} /$ day of grapefruit juice for 7 days causes significant inhibition of the enzyme causing an increase in the UFF/UFE ratio, reduction of PRA and mild hypokalemia (57).

\section{OTHER DISEASES}

\section{Ectopic ACTH Syndrome}

Eighty per cent of patients with Cushing's syndrome have hypertension, and in the subgroup of patients with ectopic ACTH syndrome this increases to over $95 \%$. The severity of hypertension is a key factor in predicting morbidity and mortality from the disease, yet its pathogenesis has been poorly understood. The ectopic ACTH syndrome is characterized by mineralocorticoid excess, with hypokalemic alkalosis found in $95-100 \%$ of cases, in contrast to $<10 \%$ in other forms of Cushing's syndrome. Although elevated plasma levels of deoxycorticosterone have been postulated to play a role, it is the level of cortisol secretion, which correlates best with the degree of mineralocorticoid excess.

ACTH has no direct effect on $11 \alpha$-HSD2, but the enzyme is saturated in ectopic ACTH syndrome by very high concentrations of ACTH-dependent $11 \alpha-$ HSD substrates such as cortisol and corticosterone. Both the urinary ratio of $\mathrm{THF}+$ allo-THF/THE and UFF/UFE are elevated, not because of impaired $11 \alpha-$ HSD2 activity, but because of substrate saturation (58) (figure $5 \mathrm{~B}$ ). In severe hypercortisolism all available cortisol cannot be inactivated to cortisone and "spills over" onto the MR to cause mineralocorticoid hypertension (15).

\section{Renal Disease}

The human kidney is the principal site of cortisol to cortisone metabolism in vivo. Patients with chronic renal failure have a prolonged plasma cortisol half-life (2.9 hours compared to 2.1 hours in controls) (59). The same is true for prednisolone, but not for dexamethasone, no doubt reflecting the observation that cortisol and prednisolone are better substrates than dexamethasone for $11 \alpha$-HSD2. Plasma cortisone concentrations are reduced in patients with renal disease (60) with an inverse correlation between cortisone values and plasma creatinine. Because of the negative feedback mechanism and concomitant fall in cortisol secretion rate, plasma cortisol concentrations remain 
unchanged. Impaired $11 \alpha-H S D 2$ activity in patients with renal disease might underpin the increased sodium retention observed in some pathologies, notably nephrotic syndrome. ACE inhibitors are known to increase renal $11 \alpha-\mathrm{HSD} 2$ activity and this, in part, may explain their natriuretic effect (61).

\section{Liver Disease}

Activation of MR in patients with liver cirrhosis leads to renal sodium retention and hypokalemia. The same is described during alcoholic and non-alcoholic chronic liver disease or bile duct obstruction where an increase in (THF+allo-THF)/THE ratio is present as a consequence of an inhibitory effect of bile acid on $11 \alpha$-HSD2 activity (62).

\section{Fetal Growth}

Glucocorticoid excess in uterus decreases fetal growth and the high levels of placental $11 \alpha-\mathrm{HSD} 2$ may protect the fetus from maternal glucocorticoid excess. Impaired enzymatic activity causing an excess of glucocorticoid in uterus can lead to the poor growth rate seen in many children with AME (63). Impaired placental $11 \alpha$-HSD2 activity has been associated with intrauterine growth restriction and with programming of hypertension in adult life (64).

\section{Preeclampsia}

Sodium retention is a feature in preeclampsia and pregnancy-induced hypertension caused probably by activation of MR. Progesterone and its metabolites can favor this by inhibiting $11 \alpha$-HSD2 (65). Reduced $11 \alpha$-HSD2 expression has been reported in placentas of women with preeclampsia and pregnancy induced hypertension (66).

\section{CONCLUSION}

1 l $\alpha$ HSD is a key enzyme for cortisol metabolism. Its activity in converting $\mathrm{F}$ to its inactive metabolite $\mathrm{E}$ regulates at "pre-receptor" site the action of glucocorticoid steroids in the body. The isozyme type II is involved in sodium and potassium homeostasis giving specificity to aldosterone for the mineralocorticoid receptor. AME syndrome is caused by total or partial $11 \alpha-\mathrm{HSD} 2$ deficiency and is characterized by hypertension, suppressed PRA and aldosterone and hypokalaemia. It represents a spectrum of mineralocorticoid hypertension with severity reflecting the underlying genetic defect in the $11 \alpha-\mathrm{HSD} 2$, from very severe and life threatening to mild. Several acquired forms of AME exist. Licorice, carbenoxolone and flavonoids may cause sufficient $11 \alpha$-HSD2 inhibition to produce metabolic and clinical disorders. Mineralocorticoid excess is also a feature of the ectopic ACTH syndrome, because $11 \alpha$-HSD2 is overwhelmed by its substrate cortisol. Polymorphic variability in the HSD11B2 gene determines salt sensitivity and might play a role in patients with "essential" hypertension. Impaired $11 \alpha-\mathrm{HSD} 2$ activity in patients with renal or hepatic disease or in preeclampsia might be involved in sodium retention in these diseases.

\section{REFERENCES}

1. Stewart PM. Mineralocorticoid hypertension. Lancet 1999;353(9161):1341-7.

2. White PC, Mune T, Agarwal AK. 11 ctHydroxysteroid dehydrogenase and the syndrome of apparent mineralocorticoid excess. Endocr Rev 1997;18(1):135-56.

3. Wilson RC, Nimkarn S, New Ml. Apparent mineralocorticoid excess. Trends Endocrinol Metab 2001;12(3):104-11.

4. Albiston AL, Obeyesekere VR, Smith RE, Krozowski ZS. Cloning and tissue distribution of the human $11 \alpha-$ hydroxysteroid dehydrogenase type 2 enzyme. Mol Cell Endocrinol 1994;105:R11-R17.

5. Vogt B, Frey BM, Frey FJ. $11 \alpha$-Hydroxysteroid dehydrogenase: pathophysiology. Adv Nephrol Necker Hosp 1999;29:127-48.

6. Kitanaka S, Tanae A, Hibi I. Apparent mineralocorticoid excess due to $11 \alpha$-hydroxysteroid dehydrogenase deficiency: a possible cause of intrauterine growth retardation. Clin Endocrinol (Oxf) 1996;44:353-9.

7. Edwards CR, Stewart PM, Burt D, Brett L, Mclntyre MA, Sutanto WS, et al. Localization of $11 \alpha$-hydroxysteroid dehydrogenase - tissue specific protector of the mineralocorticoid receptor. Lancet 1988;2(8618):986-9.

8. Funder JW, Pearce PT, Smith R, Smith AI. Mineralocorticoid action: target tissue specificity is enzyme, not receptor, mediated. Science 1988;242(4878):583-5.

9. Arriza JL, Weinberger C, Cerelli G, Glaser TM, Handelin $B L$, Housman DE, et al. Cloning of human mineralocorticoid receptor complementary DANN: structural and functional kinship with the glucocorticoid receptor. Science 1987;237(4812):268-75.

10. Stewart PM, Corrie JE, Shackleton CH, Edwards CR. Syndrome of apparent mineralocorticoid excess. A defect in the cortisol-cortisone shuttle. J Clin Invest 1988;82(1):340-9.

11. Stewart PM, Krozowski ZS. 11 $\alpha$-Hydroxysteroid dehydrogenase. Vitam Horm 1999;57:249-324.

12. Whitworth JA, Stewart PM, Burt D, Atherden SM, Edwards CR. The kidney is the major site of cortisone production in man. Clin Endocrinol Oxf 1989;31(3):355-61.

13. Shackleton $\mathrm{CH}$, Rodriguez J, Arteaga E, Lopez JM, Winter JS. Congenital $11 \alpha$-hydroxysteroid dehydrogenase deficiency associated with juvenile hypertension: Corti- 
costeroid metabolite profiles of four patients and their families. Clin Endocrinol Oxf 1985;22(6):701-12.

14. Monder C, Shackleton CH, Bradlow HL, New MI, Stoner $\mathrm{E}$, lohan $\mathrm{F}$, et al. The syndrome of apparent mineralocorticoid excess: its association with $11 \alpha$-dehydrogenase and $5 \alpha$-reductase deficiency and some consequences for corticosteroid metabolism. J Clin Endocrinol Metab 1986;63(3):550-7.

15. Palermo M, Shackleton CHL, Mantero F, Stewart PM. Urinary free cortisone and the assessment of $11 \alpha$-hydroxysteroid dehydrogenase activity in man. Clin Endocrinol (Oxf) 1996;45:605-11.

16. Palermo M, Delitala G, Mantero F, Stewart PM, Shackleton CHL. Congenital deficiency of $11 \alpha$-hydroxysteroid dehydrogenase (apparent mineralocorticoid excess syndrome): diagnostic value of urinary free cortisol and cortisone. J Endocrinol Invest 2001;24:17-23.

17. Ulick S, Tedde R, Mantero F. Pathogenesis of the type 2 variant of the syndrome of apparent mineralocorticoid excess. J Clin Endocrinol Metab 1990;70(1):200-6.

18. Mantero F, Palermo M, Petrelli MD, Tedde R, Stewart PM, Shackleton CHL. Apparent mineralocorticoid excess: Type I and type II. Steroids 1996;61:193-6.

19. Werder E, Zachmann M, Vollmin JA, Veyrat R, Prader A. Unusual steroid excretion in a child with low renin hypertension. Res Steroids 1974;6:385-9.

20. New MI, Levine LS, Biglieri EG, Pareira J, Ulick S. Evidence for an unidentified steroid in a child with apparent mineralocorticoid hypertension. J Clin Endocrinol Metab 1977;44(5):924-33.

21. Ulick S, Levine LS, Gunczler P, Zanconato G, Ramirez LC, Rauh W, et al. A syndrome of apparent mineralocorticoid excess associated with defects in the peripheral metabolism of cortisol. J Clin Endocrinol Metab 1979;49(5):757-64.

22. Oberfield SE, Levine LS, Carey RM, Greig F, Ulick S, New MI. Metabolic and blood pressure responses to hydrocortisone in the syndrome of mineralocorticoid excess. J Clin Endocrinol Metab 1983;56:332-7.

23. Edwards CRW, Stewart PM, Nairn IM, Grieve J, Shackleton CHL. Cushing's disease of the kidney. J Endocrinol 1985; 104(S):53 (abstr).

24. Krozowski Z, Funder JW. Renal mineralocorticoid receptors and hippocampal corticosterone-binding site have identical intrinsic steroid specificity. Proc Nat Acad Sci USA 1983;80:6056-60.

25. Ulick S, Chan CK, Rao KN, Edassery J, Mantero F. A new form of the syndrome of apparent mineralocorticoid excess. J Steroid Biochem 1989;32:209-12.

26. Monder C, Shackleton CHL, Bradlow HL, New MI, Stoner $\mathrm{E}$, lohan $\mathrm{F}$, et al. The syndrome of apparent mineralocorticoid excess: its association with $11 \alpha$-hydroxysteroid dehydrogenase and $5 \alpha$-reductase deficiency and some consequences for corticosteroid metabolism. J Clin Endocrinol Metab 1986;63(3):550-7.

27. Agarwal AK, Rogerson FM, Mune T, White PC. Gene structure and chromosomal localization of the human HSD 11K gene encoding the kidney (type 2) isozyme of 11 ahydroxysteroid dehydrogenase. Genomics 1995;29: 195-9.

28. Mune T, Rogerson FM, Nikkilä H, Agarwal AK, White PC. Human hypertension caused by mutations in the kidney isozyme of $11 \alpha$-hydroxysteroid dehydrogenase. Nat Genet 1995; 10:394-9.

29. Wilson RC, Harbison MD, Krozowski ZS, Funder JW, Shackleton CHL, Hanauske-Abel HM, et al. Several homozygous mutations in the gene for $11 \alpha$-hydroxysteroid dehydrogenase type 2 in patients with apparent mineralocorticoid excess. J Clin Endocrinol Metab 1995;80:3145-50.

30. Stewart PM, Krozowski ZS, Gupta A, Milford DV, Howie AJ, Sheppard MC, et al. Hypertension in the syndrome of apparent mineralocorticoid excess due to mutation of the $11 \alpha$-hydroxysteroid dehydrogenase type 2 gene. Lancet 1996;347:88-91.

31. Kitanaka S, Katsumata N, Tanae A, Hibi I, Takeyama KI, Fuse $\mathrm{H}$, et al. A new compound heterozygous mutation in the $11 \alpha$-hydroxysteroid dehydrogenase type 2 gene in a case of apparent mineralocorticoid excess. J Clin Endocrinol Metab 1997;82(12):4054-8.

32. Li AR, Li KXZ, Marui S, Krozowski ZS, Batista MC, Whorwood $\mathrm{CB}$, et al. Apparent mineralocorticoid excess in a Brazilian kindred: hypertension in the heterozygote state. J Hypertension 1997; 15(12):1397-402.

33. Wilson RC, Dave-Sharma S, Wei JQ, Obeyesekere VR, Li $\mathrm{K}$, Ferrari $\mathrm{P}$, et al. A genetic defect resulting in mild lowrenin hypertension. Proc Natl Acad Sci USA 1998;95(17):10200-5.

34. Nunez BS, Rogerson FM, Mune T, Igarashi Y, Nakagawa $Y$, Phillipov $G$, et al. Mutants of $11 \alpha$-hydroxysteroid dehydrogenase (11-HSD2) with partial activity - Improved correlations between genotype and biochemical phenotype in apparent mineralocorticoid excess. J Biol Chem 1999;34:638-42.

35. Shimojo M, Stewart PM. Apparent mineralocorticoid excess syndromes. J Endocrinol Invest 1995; 18:518-32.

36. Palermo M, Gomez-Sanchez C, Roitman E, Shackleton CHL. Quantitation of cortisol and related 3-oxo-4ene steroids in urine using gas chromatography/mass spectrometry with stable isotope-labeled internal standards. Steroids 1996;61:583-9.

37. Li A, Krozowsky ZS, Pala A, Li KXZ, Shackleton CHL, Mantero $F$, et al. Molecular basis for hypertension in the "type II variant" of apparent mineralocorticoid excess. Am J Hum Genet 1998;63:370-9.

38. Tannin GM, Agarwal AK, Monder C, New MI, White PC. The human gene for $11 \alpha$-hydroxysteroid dehydrogenase. Structure, tissue distribution, and chromosomal localization. J Biol Chem 1991;266:16653-8.

39. Palermo M, Cossu M, Shackleton CHL. Cure of apparent mineralocorticoid excess by kidney transplantation. $\mathbf{N}$ Engl J Med 1998;329(24):1787-8.

40. Walker BR, Stewart PM, Shackleton CH, Padfield PL, Edwards CR. Deficient inactivation of cortisol by $11 \alpha-$ hydroxysteroid dehydrogenase in essential hypertension. Clin Endocrinol Oxf 1993;39(2):221-7.

41. Soro A, Ingram MC, Tonolo G, Glorioso N, Fraser R. Evidence of coexisting changes in 11 ohydroxysteroid dehydroge- 
nase and $5 \alpha$-reductase activity in subjects with untreated essential hypertension. Hypertension 1995;25:67-70.

42. Watson B Jr, Bergman SM, Myracle A, Callen DF, Acton RT, Warnock DG. Genetic association of $11 \alpha$-hydroxysteroid dehydrogenase type 2 (HSD 11B2) flanking microsatellites with essential hypertension in blacks. Hypertension 1996;28(3):478-82.

43. Smolenicka Z, Bach E, Schaer A, Liechti-Gallati S, Frey $\mathrm{BM}$, Frey FJ, et al. A new polymorphic restriction site in the human $11 \alpha$-hydroxysteroid dehydrogenase type 2 gene. J Clin Endocrinol Metab 1998;83(5):1814-7.

44. Brand E, Kato N, Chatelain N, Krozowski ZS, Jeunemaitre $\mathrm{X}$, Corvol $\mathrm{P}$, et al. Structural analysis and evaluation of the $11 \alpha$-hydroxysteroid dehydrogenase type $2(11 \alpha-$ HSD2) gene in human essential hypertension. J Hypertens 1998; 16:1627-33.

45. Agarwal AK, Giacchetti G, Lavery G, Nikkila H, Palermo $\mathrm{M}$, Ricketts $\mathrm{M}$, et al. CA-Repeat polymorphism in intron 1 of HSD1 1B2: effects on gene expression and salt sensitivity. Hypertension 2000;36(2): 187-94.

46. Lovati E, Ferrari P, Dick B, Jostarndt K, Frey BM, Frey FJ, et al. Molecular basis of human salt sensitivity: The role of the $11 \alpha$-hydroxysteroid dehydrogenase type 2 . J Clin Endocrinol Metab 1999;84:3745-9.

47. White PC, Agarwal AK, Li A, Nikkila H, Pratt JH, Caulfield $M$, et al. Possible association but no linkage of the HSD11B2 gene encoding the kidney isozyme of $11 \alpha-$ hydroxysteroid dehydrogenase to hypertension in Black people. Clin Endocrinol (Oxf) 2001;55(2):249-52.

48. Smith RE, Little PJ, Maguire JA, Stein-Oakley AN, Krozowski ZS. Vascular localization of the $11 \alpha$-hydroxysteroid dehydrogenase type II enzyme. Clin Exp Pharmacol Physiol 1996;23(6-7):549-51.

49. Walker BR, Connacher AA, Webb DJ, Edwards CR. Glucocorticoids and blood pressure: a role for the cortisol/cortisone shuttle in the control of vascular tone in man. Clin Sci 1992;83(2):171-8.

50. Hatakeyama H, Inaba S, Takeda R, Miyamori I. $11 \alpha-$ Hydroxysteroid dehydrogenase in human vascular cells. Kidney Int 2000;57:1352-7.

51. Souness GW, Brem AS, Morris DJ. $11 \alpha$-Hydroxysteroid dehydrogenase antisense affects vascular contractile response and glucocorticoid metabolism. Steroids 2002;67(3-4): 195-201.

52. Hadoke PW, Christy C, Kotelevtsev YV, Williams BC, Kenyon CJ, Seckl JR, et al. Endothelial cell dysfunction in mice after transgenic knockout of type 2, but not type 1, 11 chydroxysteroid dehydrogenase. Circulation 2001;104(23):2832-7.

53. Armanini D, Fiore C, Mattarello MJ, Bielenberg J, Palermo M. History of the endocrine effect of licorice. Exp Clin Endocrinol Diabetes 2002;110:257-61.

54. Whorwood CB, Sheppard MC, Stewart PM. Licorice inhibits $11 \alpha$-hydroxysteroid dehydrogenase messenger ribonucleic acid levels and potentiates glucocorticoid hormone action. Endocrinology 1993; 132:2287-92.

55. Bernardi M, D'Intino PE, Trevisani F, Cantelli-Forti G, Raggi MA, Turchetto $E$, et al. Effect of prolonged ingestion of graded doses of licorice by healthy volunteers. Life Sci 1994;55:863-72.

56. Stewart PM, Murry BA, Mason JI. Human kidney $11 \alpha-$ hydroxysteroid dehydrogenase is a high affinity nicotinamide adenine dinucleotide-dependent enzyme and differs from the cloned type I isoform. J Clin Endocrinol Metab 1994;79(2):480-4.

57. Lee YS, Lorenzo BJ, Koufis T, Reidenberg MM. Grapefruit juice and its flavonoids inhibit $11 \alpha$-hydroxysteroid dehydrogenase. Clin Pharmacol Therapy 1996;59:62-71.

58. Stewart PM, Walker BR, Holder G, O'Halloran D, Shackleton $\mathrm{CHL}$. $11 \alpha$-Hydroxysteroid dehydrogenase activity in Cushing's syndrome: Explaining the mineralocorticoid excess state of the ectopic adrenocorticotropin syndrome. J Clin Endocrinol Metab 1995;80:3617-20.

59. Kawai S, Ichikawa Y, Homma M. Differences in metabolic properties among cortisol, prednisolone, and dexamethasone in liver and renal diseases: accelerated metabolism of dexamethasone in renal failure. $\mathbf{J}$ Clin Endocrinol Metab 1985;60(5):848-54.

60. Srivastava LS, Werk EE Jr, Thrasher K, Sholiton LJ, Kozera $R$, Nolten W, et al. Plasma cortisone concentration as measured by radioimmunoassay. J Clin Endocrinol Metab 1973;36(5):937-43.

61. Riddle MC, McDaniel PA. Renal 11 chydroxysteroid dehydrogenase activity is enhanced by ramipril and captopril. J Clin Endocrinol Metab 1994;78(4):830-4.

62. Quattropani C, Vogt B, Odermatt A, Dick B, Frey BM, Frey FJ. Reduced activity of $11 \alpha$-hydroxysteroid dehydrogenase in patients with cholestasis. J Clin Invest $2001 ; 108(9): 1299-305$.

63. McTernan CL, Draper N, Nicholson H, Chalder SM, Driver $P$, Hewison $M$, et al. Reduced placental $11 \alpha$-hydroxysteroid dehydrogenase type 2 mRNA levels in human pregnancies complicated by intrauterine growth restriction: an analysis of possible mechanisms. J Clin Endocrinol Metab 2001;86(10):4979-83.

64. Lindsay RS, Lindsay RM, Edwards CRW, SeckI JR. Inhibition of $11 \alpha$-hydroxysteroid dehydrogenase in pregnant rats and the programming of blood pressure in the offspring. Hypertension 1996;27:1200-4.

65. Quinkler M, Johanssen S, Grossmann C, Bähr V, Müller M, Oelkers W, et al. Progesterone metabolism in the human kidney and inhibition of 11 -hydroxysteroid dehydrogenase type 2 by progesterone and its metabolites. J Clin Endocr Metabol 1999;84(11):4165-71.

66. SchoofE, Girst M, Frobenius W, Kirschbaum M, Dörr HG, Rascher W, et al. Decreased gene expression of 1lathydroxysteroid dehydrogenase type 2 and 15-hydroxyprostaglandin dehydrogenase in human placenta of patients with preeclampsia. J Clin Endocrin Metabol 2001;86(3):1313-7.

67. Nikkila H, Tannin GM, New MI, Taylors NF, Kalaitzoglu G, Monder $G$, et al. Defect in HSDI gene encoding $11 \alpha-$ hydroxysteroid dehydrogenase are not found in patient with mineralocorticoid excess or 11-oxo reductase deficiency. J Clin Endocrinol Metab 1993;77:687-91.

\section{Endereço para correspondência:}

Mario Palermo

Institute of Endocrinology, University of Sassari

Viale S. Pietro 43

07100 Sassari, Italy

Fax: 039-228070

e-mail: mariocp@in.it 